\title{
ДРЕВНЕТЮРКСКИЕ ОГРАДЫ АКБАУЫР
}

\section{() 2020 г. Е. А. Дмитриев, А. И. Кукушкин, И. А. Кукушкин}

Малочисленность исследованных раннесредневековых памятников в Центральном Казахстане актуализирует интерес к каждому новому изученному комплексу. Древнетюркские ограды Акбауыр (Шетский р-н, Карагандинская обл.) представляли собой вытянутый дугой комплекс из шести сооружений кудыргинского и яконурского типов. Определенный интерес вызывает миниатюрный каменный ящик в ограде № 3. Подобные объекты являются отличительной особенностью ранней группы древнетюркских комплексов Алтая и продолжают традицию булан-кобинской культуры. Подтверждает культурную принадлежность оград Акбауыр иконографический облик поясного антропоморфного изваяния. Первые успехи в изучении хуннских комплексов Центрального Казахстана открывают новые возможности для уточнения нижней хронологической границы древнетюркских памятников региона, которая может быть определена второй половиной VI в., учитывая сопоставимость данных радиоуглеродного анализа и исторических свидетельств. Противоположная ситуация сложилась с верхней границей, которая остается гипотетичной и основывается на исчезновении традиции возведения четырехугольных оград у кыпчакских племен. Во всяком случае, на сопредельных территориях, по мнению ряда исследователей, она ограничена X в.

Ключевые слова: археология, Центральный Казахстан, Средневековье, древнетюркская эпоха, четырехугольные оградки, антропоморфное изваяние

\section{Введение}

Степень изученности древнетюркских памятников Центрального Казахстана конкретизирована довольно четко [Касенова, 2019; Дмитриев, Жусупов, 2018, с. 144], что позволяет избежать в рамках данной статьи излишне «раздутой» историографической преамбулы. Однако в последнее время появились и новые материалы, дополняющие базу источников о раннесредневековой истории региона.

В 2018 г. были опубликованы результаты изучения комплекса Кабантау, расположенного в долине реки Атасу, где раскопана цепочка из шести многоплитных оград, в которых обнаружены бронзовая пряжка с железным язычком, железная пластина с отверстиями и фрагментирован- ные кости животного [Бейсенов и др., 2018].

Масштабные работы проведены экспедицией Сарыаркинского археологического института под эгидой Международной тюркской академии на двух памятниках древнетюркского времени, расположенных в предгорьях Едирея, на северо-востоке Каркаралинского района [Кукушкин и др., 2019а; 2019б]. На святилище Ащекен Сораны сплошным раскопом охвачены цепочка из восьми оград различной формы, шесть каменных курганов с попарно соединенными насыпями, содержавших подквадратные ограждения, а также курган с отходящей в восточном направлении каменной выкладкой. Культово-ритуальный характер комплекса подтверждается 
отсутствием захоронений и объясняет малочисленность обнаруженных предметов, представленных фрагментами бронзовых застежки, ножа и стержневидного псалия, а также железным наконечником стрелы.

Более значительный материал получен на могильнике Кетабан, где исследованы два захоронения лошадей в оградах, перекрытых спаренной каменной насыпью. Сопроводительный инвентарь состоит из двух железных петельчатых стремян, фрагментов удил, подпружной пряжки, колчанного крючка, а также наконечника стрелы.

Таким образом, необходимо отметить, что в последние годы наметилась положительная тенденция в области изучения погребальных и поминальных раннесредневековых памятников Центрального Казахстана. Однако накопленные материалы все же малочисленны и без систематических исследований позитивных сдвигов в ближайшие годы не предвидится, а этап первичного накопления данных может продлиться еще не одно десятиле-

тие.

\section{Материа-} ль исследования В данной статье публикуются результаты раскопок древнетюркских оград Акбауыр, проводившихся в 2019 г. экспедицией САИ при КарГУ им. академика Е. А. Букетова. Памятник находится в Шетском районе Карагандинской области, в 8,5 км северо-западнее одноименного поселка, в 4,5 км к ВЮВ от пос. Байбала, в 0,8 км южнее реки Талды и занимает относительно ровную площадку у северного подножия горы Коныркызылтау (рис. 1).

Сооружения, составлявшие комплекс древнетюркского времени, вытянуты дугой с севера на юг-юговосток. Уже до начала вскрышных работ установлено, что ограды имели существенные разрушения - часть плит завалилась или отсутствовала, каменная забутовка большей частью разбросана по периметру построек, а в сооружении № 4 наблюдалась современная грабительская воронка.

На объекте, состоящем из шести компактно расположенных оград, был разбит сплошной раскоп, подчиненный дугообразной конфигурации комплекса (рис. 2).

Сооружение № 1 представляло собой шестиплитную ограду подквадратной формы размерами $2 \times 1,9$ м, высотой до 0,6 м, стенки которой вертикально врыты в материковый грунт и имели некоторый наклон наружу. Необходимо подчеркнуть, что

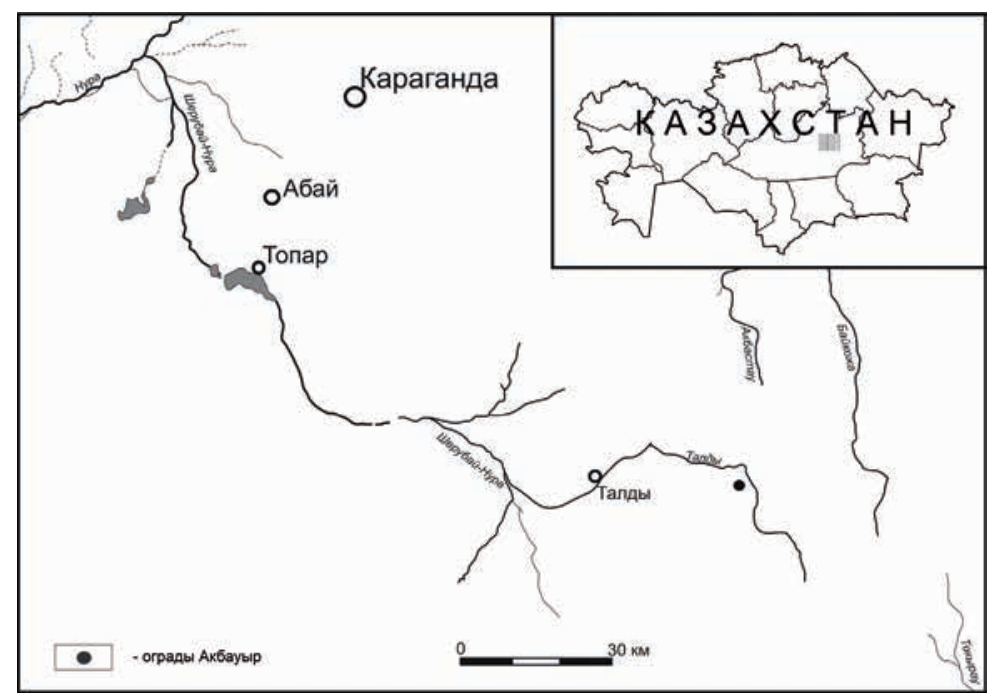

Рис. 1. Карта местонахождения оград Акбауыр. Выполнил Е. А. Дмитриев

Fig. 1. Map of the location of the fences of Akbauyr. Map by E. A. Dmitriev 
западная и южная стенки на момент раскопок состояли из четырех плит, которые, видимо, первоначально являлись цельными, т.е. комплекс, имел четырехплитную конфигурацию. Ориентировано сооружение стенками по сторонам света. Внутриоградное пространство было заполнено камнями вперемешку с землей. После выборки заполнения каких-либо дополнительных внутренних структур не обнаружено.

Сооружение № 2 - шестиплитная ограда подквадратной в плане формы, размерами $2 \times 1,9$ м, ориентированная стенками, с некоторым отклонением, по сторонам света. Высота ограды достигала 0,5 м. Часть стенок, сложенных из двух плит, представляла собой треснувшие цельные плиты. Внутриоградное пространство заполнено камнями вперемешку с землей. После выборки заполнения на уровне материка была зафиксирована овальная яма диаметром 0,3 м, глубиной до 0,1 м, в которой находились две вертикально вкопанные плитки размерами $0,1 \times 0,03-0,09 \times 0,15$ м, а заполнение представляло собой углистый грунт черного цвета. Северо-восточнее ямы № 1 зафиксирована вторая (№ 2), аналогичной формы, диаметром 0,4 м, глубиной до 0,1 м, с идентичным заполнением.

Сооружение № 3 - ограда подпрямоугольной в плане формы размерами $1,9 \times 1,7$ м, ориентированная по линии СС3-ЮЮВ, состояла на момент раскопок из трех плит (юговосточная стенка отсутствовала), врытых на ребро в материковый грунт (рис. 3). Высота стенок достигала 0,6 м. У северо-северо-западной стенки зафиксирована небольшая каменная плитка. Внутриоградное заполнение состояло из камней и грунта. После выборки забутовки в центральной части ограды был расчищен частично сохранившийся наземный каменный ящик, состоявший из вертикально поставленных плиток, имевший приблизительные размеры $0,8 \times 0,6$ м, высотой до 0,35 м, заполнение которого представляло собой углистый грунт черного цвета.

Сооружение № 4. Имело современную грабительскую воронку, которая была заглублена в материк на 0,1 м. Полностью сохранились лишь северо-восточная и северо-западная стенки, достигавшие 0,7 м в высоту. Каменная забутовка практически полностью отсутствовала. В процессе вскрышных работ обнаружено обломленное основание юго-юговосточной стенки ограды. Предположительно, сооружение имело подпрямоугольную в плане форму, размерами $1,9 \times 1,7$ м и было ориентировано по оси СВ-Ю3.

Сооружение № 5 - четырехплитная ограда подпрямоугольной в плане формы, размерами 1,5×1,4 м, ориентированная углами по сторонам света. Юго-юго-восточная часть постройки имела общую с сооружением № 6 стенку. Внутриоградное пространство было заполнено камнями и грунтом. Плиты, высотой до 0,43 м, установленные вертикально на материковый слой, частично завалились наружу. Находок не обнаружено.

Сооружение № 6 - самая крупная ограда, возможно, давшая начало для устройства остальной части комплекса, представляла собой четырехплитную конструкцию, стенки которой были установлены вертикально. Она имела подпрямоугольную в плане форму, размерами $2,4 \times 1,95$ м и была ориентирована длинной осью по линии СС3-ЮЮВ. Высота плит достигала 0,6 м. Необходимо отметить, что юго-восточная стенка завалилась наружу, а часть юго-западной, в свою очередь, отсутствовала. Внутриоградное пространство было заполнено камнями вперемешку с грунтом на высоту 0,3-0,4 м от уровня материка. После выборки заполнения сооруже- 


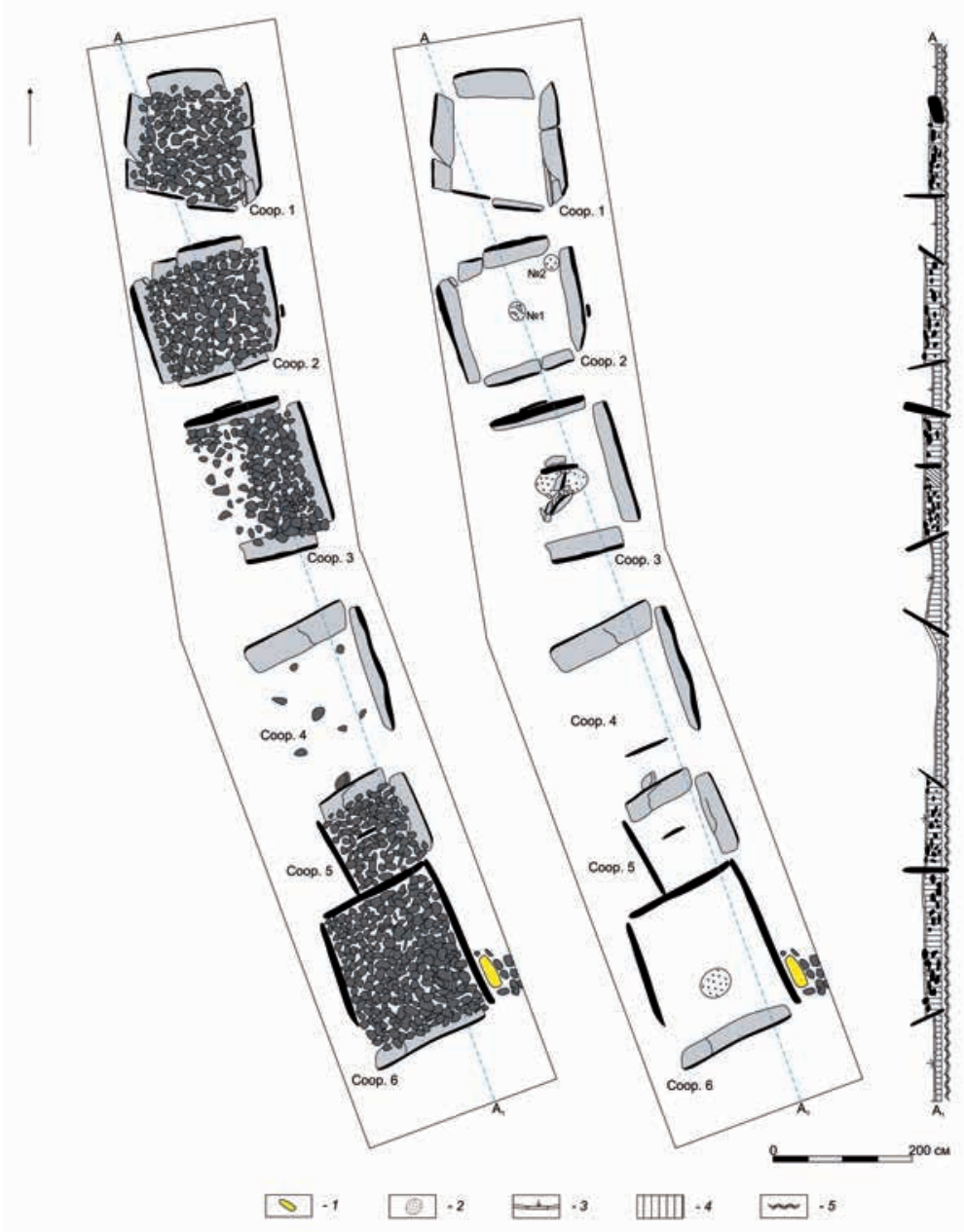

Рис. 2. План и профиль исследованных сооружений: 1 -изваяние; 2 -ямки с углистым заполнением; 3 - дерн; 4 -грунт коричневого иявета; 5 -материк. Выполнил Е. А. Дмитриев

Fig. 2. The plan and profile of the investigated structures: 1 -sculpture; 2 - pits with carbonaceous filling; 3 -turf; 4 -brown soil; 5 - the mainland. Plan by E. A. Dmitriev

ния, в центральной части, на уровне материка выявлено углубление округлой в плане формы, диаметром до 0,3 м, глубиной до 0,15 м, заполненное углистым грунтом черного цвета.

У восточной стенки ограды зафиксировано вкопанное гранитное поясное изваяние (рис. 4). Верх головы скруглен. Надбровные дуги отсутствуют. Глаза миндалевидные. Нос выполнен схематично. Усы плавно изогнуты. Рот слабо читаем, показан углублением. Подбородок заострен. Шея четко обозначена. Руки не детализированы, согнуты под прямым углом. Правая рука удерживает на уровне груди едва заметный кубок, между которым и шеей углублением оконтурен нагрудник. На боковой правой грани показано ухо, возможно, с серьгой. Размеры: $1,4 \times 0,45 \times 0,25$ м.

Под камнями, укрепляющими основание изваяния, обнаружен железный гвоздь длиной 10,4 см, имев- 


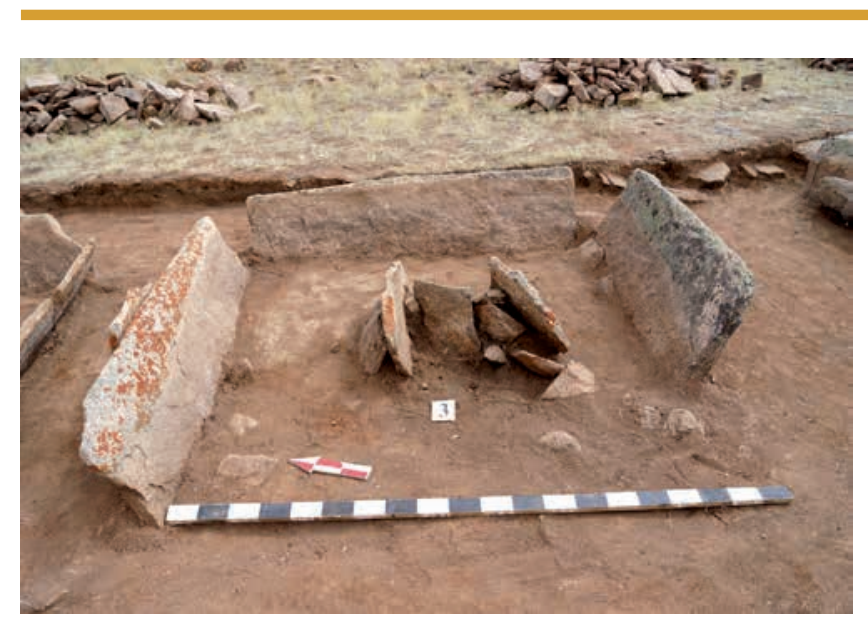

Рис. 3. Расчищенные остатки каменного ящичкка в сооружении № 3. Фото А. И. Кукушкина

Fig. 3. Cleared remains of a stone box in building No. 3 . Photo by A. I. Kukushkin

себе такую условную трактовку. Расположение комплекса дугообразной цепочкой аналогично изученному «ансамблю» многоплитных оградок яконурского типа Кабантау [Бейсенов и др., 2018, рис. 8].

Одной из отличительных особенностей оград Акбауыр является наличие наземного каменного ящичка с углистым заполнением в сооружении № 3, что было зафиксировано впервые в Центральном Казахстане. Не исключено, что они имелись и в других оградках, на что указывали от-

ший заостренный четырехгранный (квадратный в сечении со сторонами до 0,6 см) в нижней и округлый (диаметр сечения 0,7 см) в верхней части стержень. Шляпка перпендикулярна оси изделия, овальная в плане, размерами 2,6×2,4 см. На некотором расстоянии от изваяния зафиксированы поваленные и обломленные у основания балбалы. По окончанию исследования комплекса была выполнена его реставрация (рис. 5).

Анализ и обсуждение материала

Все исследованные оградки Акбауыр представляют собой четырехплитные постройки с каменноземляным заполнением внутреннего пространства. Сооружения № 5 и 6 - смежные оградки, сооружения № 1-4 - рядом стоящие, т.е. согласно В. Д. Кубареву - кудыргинского и яконурского типов соответственно [Кубарев, 1984, с. 50]. Необходимо отметить, что напротив оград № 1-4 отсутствовали внеоградные объекты, но, несмотря, на определенные предостережения автора классификации [Кубарев, 2001, с. 27], мы позволим дельные находки довольно широких плоских плиток, однако, существенное разрушение комплекса не позволяет говорить об этом однозначно. По мнению А. А. Тишкина и Н. Н. Серегина, наличие небольших ящичков в пределах оград является одной из отличительных особенностей ранней группы древнетюркских комплексов [Тишкин, Серегин, 2013, с. 77].

Сооружение № 5 выделяется на общем фоне довольно малыми размерами. Подобные небольшие оградки воспринимаются некоторыми исследователями в качестве «детских» [Кубарев, 2011, с. 234]. В двух сооружениях (№ 2 и 6) выявлены устроенные в материке ямки с углистым заполнением, диаметром 0,3-0,4 м, глубиной $0,1-0,15$ м. Причем в ограде № 2 ямка содержала две вертикально установленные каменные плитки.

Зафиксированное поясное изваяние отличается довольно хорошей детализацией (изображение лица, уха, нагрудного доспеха, кубка, обозначена поза). Его иконографический облик, бесспорно, соотносим с древнетюркской традицией. Об этом 
свидетельствуют каноническая поза с кубком в одной руке, а также ряд других признаков [Ермоленко, 2004, c. 16-17].

Вопросы назначения оград, семантики изваяний и балбалов, несмотря на выработку доминирующей модели интерпретации, периодически приводят к появлению нетривиальных гипотез. Думается, в рамках данной статьи будет не лишним вспомнить некоторые аспекты историографии этой проблематики, которые в наиболее концентрированном виде изложены в работе В. Е. Войтова «Древнетюркский пантеон и модель мироздания в культово-поминальных памятниках Монголии VI-VIII вв.» [1996].

По наиболее распространенным представлениям древнетюркские ограды имеют поминальное назначение. Однако нельзя не отметить альтернативную гипотезу об их, во всяком случае, частично погребальной принадлежности. Основываясь на документальных источниках, Л. П. Потапов предположил, что оградки могли служить в качестве места ритуального сожжения покойника вместе с инвентарем [Потапов, фотоархив МАЭ № И-1251]. В 90-е гг. ХХ в. В. А. Могильниковым [1992, с. $176 ; 1994$, с. $111-112 ; 1995$, с. 145] были опубликованы результаты работ на могильнике Кара-Коба-I, где исследованы округлые и четырехугольные сооружения с конскими захоронениями, позволившие автору предположить, что, во всяком случае, ранние оградки могли иметь как погребальную (кенотафы), так и поминальную функцию [Могильников, 1992 , с. 186]. Однако, нельзя не отметить, что выводы В. А. Могильникова все же основаны на несколько спорных сопоставлениях, на что указано В. Д. Кубаревым [2001, с. 43].

Сторонником компромиссного подхода является также Н. Н. Сере-

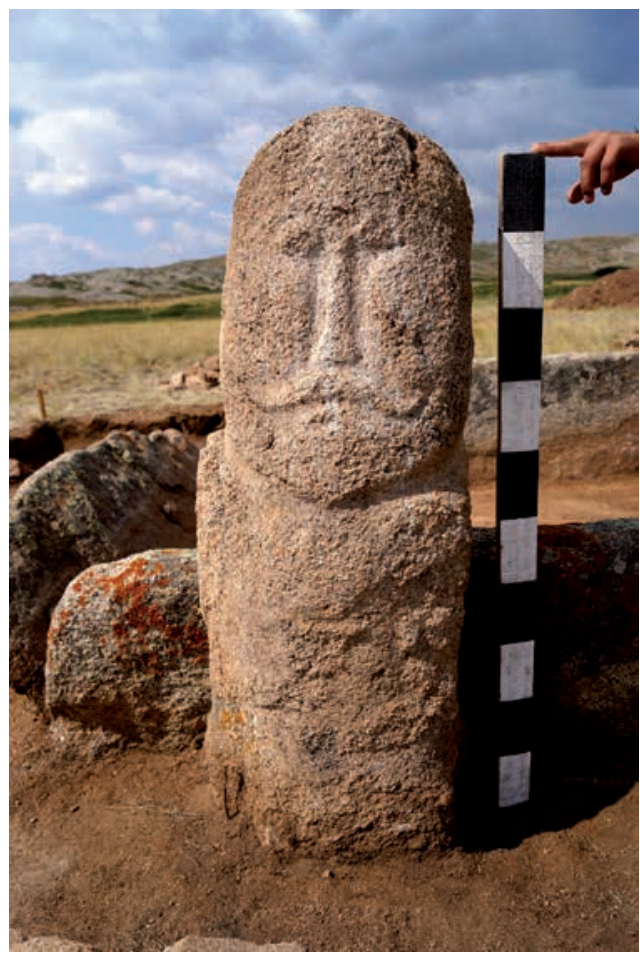

Рис. 4. Антропоморфное изваяние. Фото А. И. Кукушкина

Fig. 4. Anthropomorphic sculpture. Photo by A. I. Kukushkin

гин, обратившийся к данной проблеме на страницах ряда работ [Серегин, 2011, с. 50; Серегин, Шелепова, 2015, c. 91-106]. Основанием для таких выводов являются результаты сравнительного анализа с известными кенотафами булан-кобинской культуры [Матренин, 2005, с. 37; Матренин, Сарафанов, 2006, с. 210], с которой, по мнению исследователей, прослеживается преемственность по другим аспектам обрядности и предметному комплексу [Тишкин, Серегин, 2011, c. 28-29; Серегин, Шелепова, 2015, c. 100].

Как ранее отмечалось одним из авторов статьи [Дмитриев, Жусупов, 2018, с. 150], подвергнуть сомнению поминальное назначение центральноказахстанских оград древнетюркского времени нет оснований, при этом вполне вероятно, что более ранние 


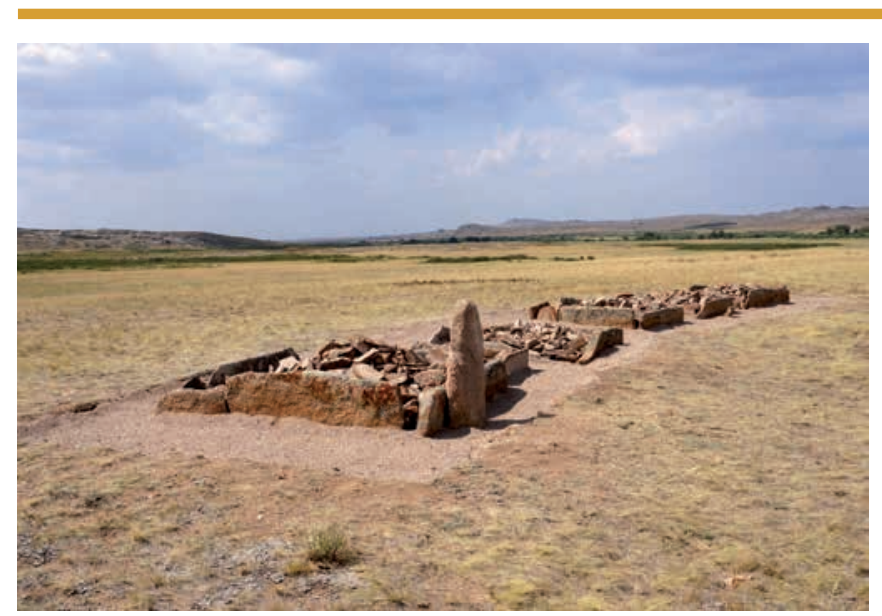

Рис. 5. Панорамный вид на реставрированные сооружения. Фото А. И. Кукушкина

Fig. 5. Panoramic view of the restored buildings. Photo by A. I. Kukushkin
[Малов, 1951; Радловъ, Меліоранскій, 1897] и неоднозначно трактовали сведения из историй Чжоу-шу и Суй-шу. Однако необходимо подчеркнуть, что сами источники и их переводы не содержат принципиально противоречивой информации.

Другая группа исследователей отождествляет изваяния с «нарисованным обликом покойного» (к примеру, Л. А. Евтюхова [1952, с. 143], С. В. Киселев [1951, с. 509, 546] и др.). Наиболее всесто-

комплексы Алтая могут по «инерции» продолжать традицию буланкобинской культуры.

В вопросе интерпретации цепочек балбалов наблюдается определенное единство мнений, заключающееся в их символическом олицетворении поверженных врагов [Войтов, 1996 и др.], основанное как на переводах китайских династийных хроник Чжоушу (629 г.), Суй-шу (636 г.) и Тан-шу (1064 г.), выполненных Н. Я. Бичуриным [1950, с. 230], Р. Ф. Итсом [1958, c. 102-103], Лю Мао-цаем [1958, s. 42] и др., так и орхонских эпиграфических памятников [Радловъ, Меліоранскій, 1897, с. 45]. Альтернативная, к слову не верифицируемая на данный момент, гипотеза об использовании балбалов в качестве коновязных столбов-сэргэ предложена П. П. Хороших [1972, с. 96-96].

Суть дискуссии о семантике антропоморфных изваяний сводится к двум противоположным взглядам: отождествлении с главным врагом или самим умершим. Сторонники первой гипотезы (А. Д. Грач [1955], Р. Ф. Итс [1958] и др.) опирались на дешифровку орхонских письменных памятников роннюю и комплексную аргументацию (на основе анализа письменных, археологических и исторических источников) она получила в статье Л. Р. Кызласова [1964].

Своеобразную позицию в этом вопросе занимал А. Н. Бернштам, трактовавший изваяния двояко, предполагая, что они могли олицетворять самого умершего, а порой и его слугу в потустороннем мире [Бернаштам, 1952, c. 143].

Датировка. На данный момент достигнуты определенные успехи в изучении памятников завершающей стадии раннего железного века - раннего средневековья Центрального Казахстана, которые позволяют на более аргументированной основе наметить нижнюю хронологическую границу древнетюркских комплексов региона.

Для нас, прежде всего, представляет интерес пересмотр времени и культурной принадлежности курганов с «усами», долгое время рассматривавшихся исключительно в качестве «визитной карточки» тасмолинской культуры. Решающим толчком к этому послужили раскопки кургана Солончанка I [Любчанский, Таиров, 
1999], давшие бесспорные факты, во всяком случае, для частичного подтверждения высказывавшейся ранее их поздней хронологической позиции [Маргулан, 1949, с. 12; Маргулан и др., 1966, с. 394].

Проведенная А. З. Бейсеновым работа по радиоуглеродному датированию ряда курганов с «усами» Центрального Казахстана [Бейсенов, 2017; Бейсенов и др., 2018] указывает на то, что хуннское население осуществляло кардинальную планиграфическую перестройку более ранних сакских погребальных комплексов в пределах II - первой половины VI в.

Именно второй половиной VI в. считаем возможным ограничить нижнюю хронологическую границу древнетюркских комплексов региона, что согласуется с историческими свидетельствами [Кляшторный, Савинов, 2005 , c. 203].

Немаловажное значение имеет отсутствие в Сарыарке памятников близких кызыл-ташскому типу, которые рассматриваются в качестве наиболее ранних в периодизации древнетюркской культуры и имеют соответственно более раннюю датировку [Тишкин, Серегин, 2011]. Наличие каменных ящиков в пределах ограды Акбауыр вряд ли может служить, во всяком случае, на данный момент, весомым аргументом для отнесения памятника к ранней группе. Тем более, согласно В. Е. Войтову четырехплитные комплексы имеют более поздний возраст [Войтов, 1996, с. 61-70].

Более детализировано решать вопрос о времени возведения оград Акбауыр в системе древнетюркских памятников Центрального Казахстана представляется преждевременным, т.к. слишком малочисленна группа аналогичных объектов исследованных в регионе. Любые сопоставления без надежных хронологических реперов или данных радиоуглеродного анализа будут страдать известной гипотетичностью. Эта проблема отмечается Г. В. Кубаревым, который указывает на большую вариативность в конструкции поминальных сооружений и зачастую отсутствие какихлибо находок, а значит оснований для их датирования и хронологии [Кубарев, 2011, с. 219].

\section{Заключение}

Резюмируя, авторы статьи в целом солидарны с мнением Г. В. Кубарева и не считают возможным принять ту или иную схему датирования, основанную на типологическом анализе древнетюркских оград для сопредельных регионов [Войтов, 1996, с. 61-70; Кубарев, 1984, с. 50; Савинов, 1984; Шелепова, 2011] и определяют время возведения исследованного комплекса широким хронологическим диапазоном в пределах второй половины VI в. - VIII в., где нижняя граница «подпирается» хуннскими комплексами, а верхняя - распространением с IX в. кыпчакских племен [Археология СССР, 1981, c. 190], у которых традиция возведения четырехугольных оград, видимо, отмирает. Во всяком случае, на сопредельных территориях, по мнению ряда исследователей, она ограничена Х в. [Москалев и др., 1996, с. 52; Худяков, Ким, 1999, с. 23; Кубарев, 2001, c. 43].

\section{ЛИТЕРАТУРА}

1. Археология СССР. Степи Евразии в эпоху средневековья / Отв. ред. С.А. Плетнева. М.: Институт археологии АН СССР, «Наука», 1981. Т. 18. 303 с.

2. Бейсенов A.3. Курганы с «усами» Центрального Казахстана // Археологическое наследие Центрального Казахстана: изучение и сохранение. Сб. научн. статей, посвящ. 70-летию организации ЦКАЭ Академии наук Казахстана. Алматы: НИЦИА «Бегазы-Тасмола», 2017. Т. 2. С. 31-37. 
3. Бейсенов А.З., Хасенова Б.М., Ахияров И.К., Дуйсенбай Д.Б. Курган с «усами» Кабантау в Центральном Казахстане // Вестник Дагестанского научного центра. 2018. № 71. C. 64-76.

4. Бернштам А.Н. Историко-археологические очерки Центрального Тянь-Шаня и Памиро-Алтая // МИА. М.-Л.: Изд-во АН СССР, 1952. Т. 26. 344 с.

5. Бичурин Н.Я. Собрание сведений о народах, обитавших в Средней Азии в древние времена. М.-Л.: Изд-во АН СССР, 1950. Т. 1. 381 с.

6. Войтов В.E. Древнетюркский пантеон и модель мироздания в культовопоминальных памятниках Монголии VI-VIII вв. М.: Изд-во Государственного музея Востока, 1996. 152 с.

7. Грач А.Д. Каменные изваяния западной Тувы (К вопросу о погребальном ритуале тугю) // Сб. МАЭ. 1955. Т. XVI. С. 401-431.

8. Дмитриев Е.А., Жусупов Д.С. Тюркские ограды могильника Танабай в контексте исследований раннесредневековых памятников Центрального Казахстана // ТиПАИ. 2018. № 1 (21). С. 144-154.

9. Евтюхова Л.А. Каменные изваяния Южной Сибири и Монголии // МИА СССР. М.: Изд-во АН СССР, 1952. № 24. С. 72-120.

10. Ермоленко Л.Н. Средневековые каменные изваяния казахстанских степей (типология, семантика в аспекте военной идеологии и традиционного мировоззрения). Новосибирск: Изд-во ИАЭт СО РАН, 2004. 132 с.

11. Итс Р.Ф. О каменных изваяниях в Синьцзяне // СЭ. 1958. № 2. С. 100-103.

12. Касенова А.Д. Изучение тюркских каменных изваяний Сарыарки на современном этапе // Поволжская археология. 2019. № 2 (28). С. 47-60.

13. Киселев С.В. Древняя история Южной Сибири. М.: Изд-во АН СССР, 1951. $635 \mathrm{c}$.

14. Клямторный С.Г., Савинов Д.Г. Степные империи древней Евразии. СПб.: Филфак СПбГУ, 2005. 346 с.

15. Кубарев В.Д. Древнетюркские изваяния Алтая. Новосибирск: Наука, 1984. $232 \mathrm{c}$.

16. Кубарев В.Д. Изваяние, оградка, балбалы: о проблемах типологии, хронологии и семантики древнетюркских поминальных сооружений Алтая и сопредельных территорий // Алтай и сопредельные территории в эпоху средневековья. Барнаул: Издво АлтГУ, 2001. С. 24-54.

17. Кубарев Г.В. Оградки кудыргинского типа в урочище Ак-Кообы (юговосточный Алтай) // Вестник НГУ. Сер.: История, филология. 2011. Т. 10, вып. 7: Археология и этнография. С. 219-235.

18. Кукушкин И.А., Дмитриев Е.А., Кукушкин А.И. Предварительные результаты исследований памятников тюркского времени Центрального Казахстана в 2018 году // Кочевые империи Евразии в свете археологических и междисциплинарных исследований: сб. науч. ст. IV междунар. конгресса средневековой археологии евразийских степей, посвящ. 100-летию российской академической археологии (г. Улан-Удэ, 16-21 сентября 2019 г.). Улан-Удэ: БНЦ СО РАН, 2019а. Кн. 1. С. 135-137.

18. Кукушкин И.А., Ломан В.Г., Кукушкин А.И., Дмитриев Е.А., Шариязданов $O . K$. Археологические исследования объекта тюркского периода «Ащекен Сораны» // Алтаистика, тюркология, монголистика. 2019б. № 1. С. 49-126.

19. Кызласов Л.Р. О назначении древнетюркских каменных изваяний, изображающих людей // СА. 1964. № 2. С. 27-39.

20. Любчанский И.Э., Таиров А.Д. Археологическое исследование комплекса курган с «усами» Солончанка I // Курган с «усами» Солончанка I: сб. науч. тр. Челябинск: Изд-во «Челяб. гос. ун-т», 1999. С. 5-62.

21. Малов С.Е. Памятники древнетюркской письменности. Тексты и исследования. М.-Л.: Изд-во АН СССР, 1951. 451 с. 
22. Маргулан А.Х. Отчет о работах Центрально-Казахстанской археологической экспедиции 1947 года // Известия АН КазССР. Сер. археол. 1949. Вып. 2. С. 3-36.

23. Маргулан А.Х., Акишев К.А., Кадырбаев М.К., Оразбаев А.М. Древняя культура Центрального Казахстана. Алма-Ата: «Наука» КазССР, 1966. 445 с.

24. Матренин C.C. Способы захоронения населения Горного Алтая во II в. до н. э. - V в. до н. э. // Изучение историко-культурного наследия народов Южной Сибири. Горно-Алтайск: АКИН, 2005. Вып. 2. С. 35-51.

25. Матренин С.С., Сарафанов Д.Е. Классификация оградок тюркской культуры Горного Алтая // Изучение историко-культурного наследия народов Южной Сибири. Горно-Алтайск: АКИН, 2006. Вып. 3-4. С. 203-218.

26. Могильников В.А. Древнетюркские оградки Кара-Коба-I // Материалы к изучению прошлого Горного Алтая. Горно-Алтайск: ГАНИИИЯЛ, 1992. С. 175-212.

27. Могильников В.A. Культовые кольцевые оградки и курганы Кара-Коба-I // Археологические и фольклорные источники по истории Алтая. Горно-Алтайск: ГАНИИИЯЛ, 1994. С. 94-116.

28. Могильников В.A. К проблеме происхождения древних тюрок Алтая // Алтай и тюрко-монгольский мир. Горно-Алтайск: ГАИГИ, 1995. С. 142-145.

29. Москалев М.И., Табалдиев К.Ш., Митько О.А. Культура средневекового населения Внутреннего Тянь-Шаня и сравнительный анализ с сопредельными регионами Центральной Азии. Бишкек: КНГУ, НГУ, 1996. 259 с.

30. Потапов Л.П. Материалы, хранящиеся в Музее антропологии и этнографии имени Петра Великого РАН (фотоархив МАЭ № И-1251: 97-100, 146-153, 197-198, 200-201, 630-640).

31. Радловъ В.В., Меліоранскій П.М. Древне-тюркскіе памятники въ КошоЦайдамь // Сборникъ трудовъ Орхонской экспедиціи. СПб.: Типографія Императорской Академіи наукъ, 1897. T. IV. 45 с.

32. Савинов Д.Г. Народы Южной Сибири в древнетюркскую эпоху. Л.: Изд-во ЛГУ, 1984. $174 \mathrm{c.}$

33. Серегин Н.Н. Объекты «ритуального» характера в составе погребальных комплексов тюркской культуры // Древние и современные культовые места Алтая. Барнаул: ООО «Печатная компания АРТИКА», 2011. С. 49-54.

34. Серегин Н.Н., Шелепова Е.В. Тюркские ритуальные комплексы Алтая (2-я половина I тыс. до н.э.): систематизация, анализ, интерпретация. Барнаул: Азбука, 2015. $168 \mathrm{c}$.

35. Тишкин А.А., Серегин Н.Н. Предметный комплекс из памятников кызылташского этапа тюркской культуры (2-я половина V - 1-я половина VI в. н.э.): традиции и новации // ТиПАИ. 2011. Вып. 6. С. 14-32.

36. Тишкин А.А., Серегин Н.Н. Тюркские оградки как одна из форм сооружения кенотафов в раннем средневековье // ТиПАИ. 2013. Вып. № 2 (8). С. 75-81.

37. Хороших П.П. Оленные камни Монголии и Бурятии // Монголын эртний туух соелын зарим судлал. SА. Улаанбаатар, 1972. Т. V. С. 93-96.

38. Худяков Ю.С., Ким С.А. Древнетюркские поминальные памятники в долине p. Нарын в Туве // Памятники культуры древних тюрок в Южной Сибири и Центральной Азии. Новосибирск: Изд. центр НГУ, 1999. С. 23-54.

39. Шелепова E.B. Систематизация и интерпретация ритуальных оградок тюркской культуры Алтая // Вестник НГУ. Сер.: История, филология. 2011. Т. 10, вып. 5: Археология и этнография. С. 212-227.

40. Liu Mau-tsai. Die chinesischen Nachrichten zur Geschichte der Ost-Türken (T'uküe). Wiesbaden: O. Harrassowitz, 1958. I. 831 s. 


\section{Сведения об авторах:}

Дмитриев Евгений Анатольевич - аспирант, Алтайский государственный университет (г. Барнаул, РФ), младший научный сотрудник, Сарыаркинский археологический институт, Карагандинский государственный университет им. Е.А. Букетова (г. Караганды, Казахстан); yevgenii1992@mail.ru

Кукушкин Алексей Игоревич - PhD, научный сотрудник, Сарыаркинский археологический институт, Карагандинский государственный университет им. Е.А. Букетова (г. Караганды, Казахстан); tatarlandia@mail.ru

Кукушкин Игорь Алексеевич - кандидат исторических наук, ведущий научный сотрудник, Сарыаркинский археологический институт, Карагандинский государственный университет им. Е.А. Букетова (г. Караганды, Казахстан); sai@ksu.kz

\section{«АҚБАУЫР» ЕЖЕЛГІ ТУРКІ ҚОРШАУЛАРЫ}

\section{Е. А. Дмитриев, А. И. Кукушкин, И. А. Кукушкин}

Орталық Қазақстандағы зерттелген ерте ортағасырлық ескерткіштердің аздығы зерттелетін әрбір жаңа кешенге қызығушылық танытады. Ақбауырдың ежелгі түрік қоршаулары (Қарағанды облысының Шет ауданы) Кудиргин және Яконур типіндегі 6 құрылымның созылған кешені болып табылады. № 3 қоршаудағы миниатюралық тас қорапшасы ерекше қызығушылық тудырады. Мұндай заттар Алтайдың ежелгі түркі кешендерінің ерекшелігі болып табылады және Булан-Кобин мәдениетінің дәстүрін жалғастырады. Белбеу антропоморфтық мүсіннің иконографиялық көрінісі Ақбауыр қоршауларының мәдени жақындығын растайды. Орталық Қазақстанның ғұндық кешендерін зерттеудегі алғашқы жетістіктер VI ғасырдың екінші жартысында анықталуы мүмкін аймақтың ежелгі түркі ескерткіштерінің төменгі хронологиялық шекарасын анықтауға жаңа мүмкіндіктер ашады. Қарама-қарсы жағдай гипотетикалық болып қалатын және қыпшақ тайпалары арасында төртбұрышты қоршаулар салу дәстүрінің жойылуына негізделген жоғарғы шекпен дами бастады. Қалай болғанда да, көрші территорияларда, кейбір зерттеушілердің пікірінше, бұл оныншы ғасырмен шектелген.

Түйін сөздер: археология, Орталық Қазақстан, Орта ғасыр, ежелгі түркі дәуірі, төртбұрышты қоршаулар, антропоморфтық мүсіндер

\section{ANCIENT TURKIC AKBAUYR FENCES}

\section{E. A. Dmitriev, A. I. Kukushkin, I. A. Kukushkin}

The small number of studied early medieval sites in Central Kazakhstan actualizes interest in each new studied complex. The ancient Turkic enclosures of Akbauyr (Shet district of Karagandy region) represented an elongated arc of 6 structures of the Kudyrginsky and Yakonur types. Of particular interest is the miniature stone box in the fence number 3. Such objects are a distinctive feature of the early group of ancient Turkic complexes of Altai and continue the tradition of Bulan-Kobin culture. The iconographic design of the half-length anthropomorphic sculpture confirms the cultural affiliation of the Akbauyr enclosures. The first successes in the study of the Xiongnu complexes of Central Kazakhstan open up new possibilities for clarifying the lower chronological boundary of the ancient Turkic sites of the region, which can be determined by the second half of the $6^{\text {th }}$ century, given the comparability of the data of radiocarbon analysis and historical evidence. The opposite situation has developed with the upper limit, which remains hypothetical and is based on disappearance of the tradition of erecting quadrangular enclosures among the Kipchak tribes. In any case, in neighboring territories, according to some researchers, it is limited to the $10^{\text {th }}$ century. 
Keywords: archaeology, Central Kazakhstan, the Middle Ages, the ancient Turkic era, quadrangular enclosures, anthropomorphic sculpture

\section{REFERENCES}

1. Arheologiya SSSR. 1981. Stepi Evrazii v epohu srednevekov'ya (Archeology of the USSR. Steppes of Eurasia in the Middle Ages) / Ed. Pletneva, S. A. Moscow: Institute of Archeology USR AS, «Nauka» Publ. (in Russian).

2. Beisenov, A. Z. 2017. In Beisenov, A. Z., Loman, V. G. (Eds.) Arheologicheskoe nasledie Central'nogo Kazahstana: izuchenie i sohranenie (Archaeological Heritage of Central Kazakhstan: Study and Preservation). Almaty: «Begazy-Tasmola», 31-37 (in Russian).

3. Beisenov, A. Z., Khasenova, B. M., Akhiyarov, I. K., Duisenbay, D. B. 2018. In Vestnik Dagestanskogo nauchnogo centra (Bulletin of the Dagestan Scientific Center), 71, 64-76 (in Russian).

4. Bernshtam, A. N. 1952. In Materialy i issledovaniya po arheologii SSSR (Materials and research on archeology of the USSR). Moscow-Leningrad: SR AS Publ., vol. 26 (in Russian).

5. Bichurin, N. Ya. 1950. Sobranie svedenii o narodah, obitavshih v Srednei Azii v drevnie vremena (Collection of information about the peoples who lived in Central Asia in ancient times). Moscow-Leningrad: SR AS Publ., vol. 1 (in Russian).

6. Voitov, V. E. 1996. Drevnetyurkskii panteon i model' mirozdaniya v kul'tovopominal'nyh pamjatnikah Mongolii VI-VIII vv. (The Ancient Turkic pantheon and the model of the universe in the cult-memorial monuments of Mongolia of the VI-VIII centuries). Moscow: Orient museum Publ. (in Russian).

7. Grach, A. D. 1955. In Sbornik Muzeya antropologii i etnografii (Collection of the Museum of Anthropology and Ethnography), vol. XVI, 401-431 (in Russian).

8. Dmitriev, E. A., Zhusupov, D. S. 2018. In Teoriya i praktika arheologicheskih issledovanii (Theory and practice of archaeological research), 1 (21), 144-154 (in Russian).

9. Evtyuhova, L.A. 1952. In Materialy i issledovaniya po arheologii SSSR (Materials and research on archeology of the USSR). Moscow: USSR Academy of Sciences Publ., № 24, 72-120 (in Russian).

10. Ermolenko, L.N. 2004. Srednevekovye kamennye izvayaniya kazahstanskih stepei (tipologiya, semantika $v$ aspekte voennoi ideologii $i$ tradicionnogo mirovozzreniya) (Medieval stone sculptures of the Kazakhstan steppes (typology, semantics in the aspect of military ideology and traditional worldview). Novosibirsk: Siberian branch Institute of Archeology and Ethnography RAS Publ. (in Russian). Russian).

11. Its, R. F. 1958. In Sovetskaya etnografiya (Soviet ethnography), 2, 100-103 (in

12. Kasenova, A. D. 2019. In Povolzhskaya arheologiya (The Volga river region Archeology), 2 (28), 47-60 (in Russian).

13. Kiselev, S.V. 1951. Drevnyaya istoriya Juzhnoi Sibiri (Ancient history of Southern Siberia). Moscow: USSR Academy of Sciences Publ. (in Russian).

14. Klyashtornyi, S. G., Savinov, D. G. 2005. Stepnye imperii drevnei Evrazii (Steppe empires of ancient Eurasia). Saint Petersburg: Philologie faculty of the Saint Petersburg State University Publ. (in Russian).

15. Kubarev, V. D. 1984. Drevnetyurkskie izvayaniya Altaya (Ancient Turkic sculptures of Altai). Novosibirsk: Nauka (in Russian).

16. Kubarev, V. D. 2001. In Altai i sopredel'nye territorii v epohu srednevekov'ya (Altai and adjacent territories in the Middle Ages). Barnaul: Altay State University Publ., 24-54 (in Russian). 
17. Kubarev, G. V. 2011. In Vestnik Novosibirskogo gosudarstvennogo universiteta (Bulletin of Novosibirsk State University). Series: History, philology, vol. 10, 7: Archeology and Ethnography, 219-235 (in Russian).

18. Kukushkin, I. A., Dmitriev, E. A., Kukushkin, A. I. 2019a. In Kochevye imperii Evrazii v svete arheologicheskih $i$ mezhdisciplinarnyh issledovanii (The nomadic empires of Eurasia in the light of archaeological and interdisciplinary research), 1. Ulan-Ude: Siberian brunch Buryat Scientific Center, 135-137 (in Russian).

18. Kukushkin, I. A., Loman, V. G., Kukushkin, A. I., Dmitriev, E. A., Shariyazdanov, O. K. 2019b. In Altaistika, tyurkologija, mongolistika (Altaiistics, Turkology, Mongolistics), 1, 49-126 (in Russian).

19. Kyzlasov, L. R. 1964. In Sovetskaya arheologiya (Soviet archeology), 2, 27-39 (in Russian).

20. Lyubchanskii, I. Je., Tairov, A. D. 1999. In Kurgan s «usami» Solonchanka I: sb. nauch. tr. (Barrow with Solonchanka I «mustache»: Scientific col.). Chelyabinsk: Chelyabinsk State University Publ., 5-62 (in Russian).

21. Malov, S. E. 1951. Pamyatniki drevnetyurkskoi pis'mennosti. Teksty i issledovaniya (Monuments of ancient Turkic writing. Texts and studies). Moscow-Leningrad: USSR AS Publ. (in Russian).

22. Margulan, A. Kh. 1949. In Izvestiya AN KazSSR (News of the Academy of Sciences of the Kazakh SSR). Ser. archeol., 2, 3-36 (in Russian).

23. Margulan, A. Kh., Akishev, K. A., Kadyrbayev, M. K., Orazbayev, A. M. 1966. Drevnyaya kul'tura Central'nogo Kazahstana (Ancient culture of Central Kazakhstan). Alma-Ata: «Nauka» KazSSR, 1966 (in Russian).

24. Matrenin, S. S. 2005. In Izuchenie istoriko-kul'turnogo naslediya narodov Juzhnoi Sibiri (Study of the historical and cultural heritage of the peoples of South Siberia), 2. Gorno-Altaisk: Agency for the cultural and historical heritage of the Republic of Altay Publ., 35-51 (in Russian).

25. Matrenin, S. S., Sarafanov, D. E. 2006. In Izuchenie istoriko-kul 'turnogo nasledija narodov Juzhnoi Sibiri (Studying the historical and cultural heritage of the peoples of South Siberia), 3-4. Gorno-Altaisk: Agency for the cultural and historical heritage of the Republic of Altay Publ., 203-218 (in Russian).

26. Mogil'nikov, V. A. 1992. In Materialy k izucheniyu proshlogo Gornogo Altaya (Materials for the study of the past of Altai Mountains). Gorno-Altaisk: Gorno-Altaisk Research Institute of History, Language and Literature Publ., 175-212 (in Russian).

27. Mogil'nikov, V. A. 1994. In Arheologicheskie i fol'klornye istochniki po istorii Altaya (Archaeological and folklore sources on the history of Altai). Gorno-Altaisk: GornoAltaisk Research Institute of History, Language and Literature Publ., 94-116 (in Russian).

28. Mogil'nikov, V. A. 1995. In Altai i tyurko-mongol'skii mir (Altay and the Turkic-Mongolian world). Gorno-Altaisk: Gorno-Altaisk Institute for Humanitarian Research Publ., 142-145 (in Russian).

29. Moskalev, M. I., Tabaldiev, K. Sh., Mit'ko, O. A. 1996. Kul'tura srednevekovogo naseleniya Vnutrennego Tyan'-Shanya i sravnitel'nyi analiz s sopredel'nymi regionami Central'noi Azii (Culture of the medieval population of the Inner Tien Shan and a comparative analysis with the neighboring regions of Central Asia). Bishkek: Kyrgyz National State University, Novosibirsk State University Publ. (in Russian).

30. Potapov, L. P. Materialy, hranyashhiesya v Muzee antropologii i etnografii imeni Petra Velikogo Rossiiskoi akademii nauk (Materials stored in the Peter the Great Museum of Anthropology and Ethnography of the Russian Academy of Sciences) (fotoarhiv MAE № I-1251: 97-100, 146-153, 197-198, 200-201, 630-640).

31 Radlov, V. V., Melioranskii, P. M. 1897. In Sbornik trudov Orhonskoi ekspedicii (Collection of works of the Orkhon expedition), vol. IV. Saint Petersburg: Imperial Academy of Sciences Publ. (in Russian). 
32. Savinov, D. G. 1984. Narody Juzhnoi Sibiri v drevnetyurkskuyu epohu (Peoples of southern Siberia in the ancient Turkic era). Leningrad: Leningrad State University Publ. (in Russian).

33. Seregin, N. N. 2011. In Drevnie i sovremennye kul'tovye mesta Altaya (Ancient and modern cult places of Altai). Barnaul: «Pechatnaya kompaniya ARTIKA» Publ., 49-54 (in Russian).

34. Seregin, N. N., Shelepova, E. V. 2015. Tyurkskie ritual'nye kompleksy Altaya (2-ya polovina I tys. do n.e.): sistematizaciya, analiz, interpretaciya (Turkic ritual complexes of Altai (2nd half of the I millennium BC): systematization, analysis, interpretation). Barnaul: "Azbuka" Publ. (in Russian).

35. Tishkin, A. A., Seregin, N. N. 2011. In Teoriya i praktika arheologicheskih issledovanii (Theory and practice of archaeological research), 6, 14-32 (in Russian).

36. Tishkin, A. A., Seregin, N. N. 2013. In Teoriya i praktika arheologicheskih issledovanii (Theory and practice of archaeological research), 2 (8), 75-81 (in Russian).

37. Khoroshih, P. P. 1972. In Mongolyn ertnii tuuh soelyn zarim sudlal. SA, Ulaanbaatar, vol. V, 93-96 (in Russian).

38. Khudyakov, Yu. S., Kim, S. A. 1999. In Pamyatniki kul'tury drevnih tyurok v Yuzhnoi Sibiri i Central'noi Azii (Monuments of culture of ancient Turks in South Siberia and Central Asia). Novosibirsk: Novosibirsk State University Publ., 23-54 (in Russian).

39. Shelepova, E.V. 2011. In Vestnik Novosibirskogo gosudarstvennogo universiteta (Bulletin of Novosibirsk State University). Ser.: History, philologie, vol. 10, 5: Archeology and Ethnographie, 212-227 (in Russian).

40. Liu Mau-tsai. 1958. Die chinesischen Nachrichten zur Geschichte der Ost-Türken (T'u-küe). Wiesbaden: O. Harrassowitz, I.

\section{About the Authors:}

Dmitriev Evgeniy A. Postgraduate student, Altai State University, Barnaul, Russia, junior researcher, Saryarka Archaeological Institute, Buketov Karagandy State University, Karagandy, Kazakhstan; yevgenii1992@mail.ru

Kukushkin Alexey I. PhD, researcher, Saryarka Archaeological Institute, Buketov Karagandy State University, Karagandy, Kazakhstan; tatarlandia@mail.ru

Kukushkin Igor A. Candidate of historical sciences, leading researcher, Saryarka Archaeological Institute, Buketov Karagandy State University, Karagandy, Kazakhstan; sai@ksu.kz

\footnotetext{
Мүдделер қақтығысы туралы ақпаратты ашу. Авторлар мүдделер қақтығысының жоқтығын мәлімдейді. / Раскрытие информации о конфликте интересов. Авторы заявляют об отсутствии конфликта интересов. / Disclosure of conflict of interest information. The authors claims no conflict of interest.

Мақала туралы ақпарат / Информация о статье / Information about the article. Редакцияға түсті / Поступила в редакцию / Entered the editorial office: 24.04.2020. Рецензенттер мақұлдаған / Одобрено рецензентами / Approved by reviewers: 01.06.2020. Жариялауға қабылданды / Принята к публикации / Accepted for publication: 11.06.2020.
} 